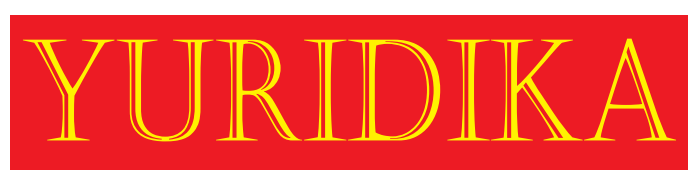

Volume 33 No. 2, Mei 2018

DOI: $10.20473 /$ ydk.v33i2.7380

Fakultas Hukum Universitas Airlangga, Jalan Dharmawangsa Dalam Selatan

Surabaya, 60286 Indonesia, $+6231-5023151 / 5023252$

Fax +6231-5020454, E-mail: yuridika@fh.unair.ac.id Yuridika (ISSN: 0215-840X | e-ISSN: 2528-3103)

FAKULTAS HUKUM UNIVERSITAS AIRLANGGA by http://e-journal.unair.ac.id/index.php/YDK/index un

Article history: Submitted 17 January 2018; Accepted 5 March 2018; Available Online 1 May 2018

\title{
IMPLEMENTATION OF SYARI'AH ECONOMIC PRINCIPLES ON THE MANAGEMENT OF SYARI'AH MUTUAL FUND IN INDONESIA
}

\author{
Nunung Rodliyah dan Risti Dwi Ramasari \\ nunungradliyah@yahoo.com \\ Universitas Lampung
}

\begin{abstract}
The role of islamic financial system in Indonesia has been shown to support the creation of higher economic development, and also support the establishment of a more stable financial system, to achieve the well-being of individuals and society. The entry of islamic financial system in Indonesia made a new breakthrough in the syari'ah capital market. One of the products of syari'ah capital market is syari'ah mutual fund. Syari'ah mutual funds are contributors in the field of Syariah Economic Law. The development of sharia economic finance in Indonesia to date still in line with the business model. This is due to the development products of market-driven syari'ah financial system in fulfilling demand in the real sector. Syari'ah financial institution have not been so familiar in the midst of Indonesian society due to the new condition, is something reasonable if not widely known then syari'ah financial institution still lose many consumers than conventional financial institutions. Implementation of the transaction contract should not be contrary to the islamic Syari'ah, whether prohibited because forbidden in addition to the substance, which contains tadlis, ihtikar, ba'i najasy, garar, and usury, an because unauthorized, i.e. the order and conditions.
\end{abstract}

Keywords: Syari'ah Economics Law; Syari'ah Mutual funds; Implementation.

\begin{abstract}
Abstrak
Peran sistem keuangan Islam di Indonesia telah ditunjukkan untuk mendukung terciptanya pembangunan ekonomi yang lebih tinggi, dan juga mendukung pembentukan sistem keuangan yang lebih stabil, untuk mencapai kesejahteraan individu dan masyarakat. Masuknya sistem keuangan Islam di Indonesia membuat terobosan baru di pasar modal syari'ah. Salah satu produk dari pasar modal syari'ah adalah reksadana syari'ah. Reksadana syari'ah adalah kontributor di bidang hukum ekonomi syariah. Perkembangan pembiayaan ekonomi syariah di Indonesia hingga saat ini masih sejalan dengan model bisnis. Hal ini disebabkan oleh pengembangan produk sistem keuangan syariah yang didorong pasar dalam memenuhi permintaan di sektor riil. Lembaga keuangan syari'ah belum begitu akrab di tengah masyarakat Indonesia karena kondisi baru, adalah sesuatu yang wajar jika tidak dikenal secara luas maka lembaga keuangan syari'ah masih kehilangan banyak konsumen daripada lembaga keuangan konvensional. Penerapan akad transaksi tidak boleh bertentangan dengan syari'ah Islam, baik dilarang karena haram selain zatnya, yakni mengandung tadlis, ihtikar, ba'i najasy, garar, dan riba, maupun karena tidak sah akadnya, yakni rukun dan syarat yang tidak terpenuhi, terjadi ta'alluq, serta terjadi dua akad dalam satu transaksi secara bersamaan.
\end{abstract}

Kata Kunci: Hukum Ekonomi Syariah; Reksadana Syariah; Penerapan. 


\section{Introduction}

The life of muslims is described in fiqh, not least in economic activity; Islam has given its own guidance. ${ }^{1}$ To realize the islamic lifestyle system and institutions are required that embodied the values of islamic syari' $a h$. One form of embodiment of islamic syari'ah value is the establishment of syari'ah financial institutions. The establishment of syari'ah financial institutions is an effort toward the islamic life order especially on economic aspects. Syari'ah Financial Institution is one of the institutionalization of islamic doctrine that is currently mushrooming in the midst of modern Indonesian society. ${ }^{2}$ The sociological formation of institutions in the life of society is a process of crystallization of continuum types of norms. Institutionalization does not happen by chance and haphazard but through a long evolutionary process. Riba is forbidden in the nas after being understood by muslims is the norm after the process of usage, folkways, mores, and custom that became the guidelines of behavior of muslims then become part of social institutions. ${ }^{3}$ Since the operation of islamic financial institutions in Indonesia in 1992 which marked with the establishment of Bank Muamalah Indonesia (BMI) means the Indonesian nation has had a new financial system free of riba (bank interest) that is using the system of profit sharing.

The development of sharia economic finance in Indonesia to date still in line with the business model. This is due to the development products of market-driven syari'ah financial system in fulfilling demand in the real sector. ${ }^{4}$ Syari'ah Financial Institution have not been so familiar in the midst of Indonesian society due to the new condition, is something reasonable if not widely known then Syari'ah Financial Institution still lose many consumers than conventional financial institutions. In

\footnotetext{
${ }^{1}$ Alie Yafie, Fiqh Perdagangan Bebas (Teraju 2003).[2-3].

${ }^{2}$ One of the fastest growing LKS is BMT, according to PINBUK data of 2001 in Indonesia there are 2938 BMTs. Heri Sudarsono, Bank and Syariah Mutual Fund (Econosia 2005).[99].

${ }^{3}$ A. Djazuli dan Yadi Janwari, Lembaga-Lembaga Perekonomian Umat (PT Raja Grafindo Persada 2002).[6-9].

${ }^{4}$ Syarifah Gustiawati Mukri, 'Langkah Strategis Optimalisasi Sistem Ekonomi Syariah' (2014) 1 Jurnal Filsafat dan Budaya Hukum $<$ http://journal.uinjkt.ac.id/index.php/salam/article/ view/1521>.[17].
} 
addition to the still new understanding of the Indonesian people about syari'ah economy still minimal. Simply put, religious studies often done by muslims rarely discuss the economy of syari'ah..$^{5}$ Along with the growth of financial institutions syari'ah MUI issued a fatwa that interest, is riba is unlawful law. Set up a friend in a conventional financial institution for an existing region of Syari'ah Financial Institution forbidden. ${ }^{6}$ Observing the MUI pronouncement on bank interest gives an illustration that bank interest forbid pay attention too many aspects not based on the normative aspects of islamic law alone. In pronouncements issued by islamic mass organizations such as NU, Muhammadiyah, is also very concerned about other aspects. Like conventional markets in general, the stock market is a meeting place for sellers and buyers, since the definition of a market is a means of bringing together buyer and seller activity for a commodity or service. What is traded in capital markets is capital or funds. ${ }^{7}$ Thus, capital markets bring together the seller of capital/funds with the buyer of capital or funds. ${ }^{8}$

Based on the provisions of the syari'ah system, the capital market is part of muamalah activity. Transactions within the capital market are permitted so long as there are no transactions that are contrary to the provisions outlined by the syari'ah. If viewed from the history in Indonesia, syari'ah capital market is a new market and newly known by the people of Indonesia when compared with capital markets that have been there. Nevertheless, in the presence of halal from the market to increase the participation in the syari'ah capital market, then in the future syari'ah capital market Indonesia is very wide open to become one of the best investment world choice. Fathurrahman Djamil explained that the syariah capital market was officially launched in Indonesia on march 14, 2003 simultaneously with the signing of MOU between BAPEPAM-LK and the National Syari'ah Council of Indonesian Ulama

\footnotetext{
${ }^{5}$ A Qodri Azizy, Membangun Fondasi Ekonomi Umat (Pustaka Pelajar 2005).[32].

${ }^{6}$ MUI, 'Decision of Fatwa of Indonesian Ulema Council Number 1 of 2004 on Interest (Intersat/Fa'idah)' (Majelis Ulama Indonesia, 2017) < http://www.mui.or.id> accessed 14 June 2017. ${ }^{7}$ Nasarudin Irsan dan Indra Surya, Aspek Hukum Pasar Modal Indonesia (Kencana 2007).[10].

${ }^{8}$ Sumantoro dalam Khaerul Umam, Pasar Modal Syari'ah Dan Praktik Pasar Modal Syari'ah (Pustaka Setia 2013).[34].
} 
Council (DSN-MUI). Although it was launched since 2003, but syariah capital market instruments have been present in Indonesia in 1997. This is marked by the launch of Danareksa Syari'ah on July 3, 1997 by PT. Danareksa Investment Management.

The development of syariah capital market of Indonesia started with the issuance of syari'ah mutual fund in 1997. Mutual funds are the containers used to raise funds from the investors to be invested in securities portfolios and investment managers. ${ }^{9}$ Then followed by the emergence of Jakarta Islamic Index (JII) in 2000 and the issuance of mudharabah syari'ah bonds in 2002. In order to provide legal certainty, Bapepam-LK issued a package of syariah capital market regulation in 2006 and List of Syari'ah Securities (DES) in 2007. This has strengthened the infrastructure of syari'ah capital market. In 2008, the government first issued Government Syari'ah Securities (SBSN). Furthermore, to facilitate investors who want to transact syari'ah securities such as Syari'ah and Syari'ah Exchange Traded Funds (ETF) syari'ah has launched syari'ah online trading system in 2011 under $5 \%$ compared to total product (Syari'ah and conventional) in circulation.

Many muslims in Indonesia are still hesitant halal-haram investing mutual funds. Many are not yet sure whether mutual funds are not against islamic norms. To answer this doubt, the National Syari'ah Council of the Indonesian Ulema Council (DSN MUI) has actually issued a fatwa. 20/DSN-MUI/IV/2001 which allows muslims to invest in mutual funds, especially syari'ah mutual funds . Bapepam and LK Rules Number IX.A.13 syari'ah Mutual funds are defined as mutual funds as referred to in the Capital Market Law and its implementing regulations whose operations are not inconsistent with the principles of syari'ah in the capital market. Syari'ah mutual funds, like mutual funds, are generally an investment alternative for investors, especially small investors and investors who do not have much time and expertise to calculate risks to their investments. Mutual funds designed as a means to raise funds from people who have the capital, have a desire to make investments, but only have the time and knowledge are limited. Compared with

\footnotetext{
${ }^{9}$ Aini Masruroh, 'Konsep Dasar Investasi Reksadana' (2014) 1 Jurnal Filsafat dan Budaya Hukum.[85].
} 
conventional types of mutual funds, the development of Syari'ah mutual funds can still be said to lag far behind. Asset Under Management (AUM)/The amount of managed funds for syari'ah mutual funds actually shrank from Rp 12 trillion in early April 2015 to Rp 10.2 trillion in April 2016 or declined by about 15\%. The decline was driven by the performance of syari'ah mutual funds that are declining followed by investors who attract funds.

Despite declining the last 1 year development RDSy 10 years since 2006 is arguably phenomenal. Beginning in April 2006 there were only 17 RDSy with managed funds of Rp 474 billion, in April 2016 this number grew to 90 RDSy with a managed fund of $\mathrm{Rp} 10.2$ trillion or growing 20 times, a fantastic figure. Growth in managed funds is supported by the yield of syari'ah sector which had skyrocketed the commodity boom period 2007-2012 thus attracting the public interest to start trying to invest into RDSy. Plus RDSy can also be obtained through several Banks as a sales agent so as to expand its distribution. ${ }^{10}$ The Financial Services Authority as a regulator is continuously committed to encouraging the syariah mutual fund industry to continue to grow, as seen from the Financial Services Authority Regulation Number 19/POJK.04/2015 on Issuing and Requirements of Syari'ah Mutual funds . In this regulation, the new breakthrough is about syari' ah-based sukuk and syari'ahbased syari'ah-based securities (known as global syari'ah funds) syariah-based syari'ah funds themselves are similar to fixed income mutual funds Syari'ah which already exists but in addition to investing in sukuk and securities syari'a countries are also permitted to invest in commercial syari'ah securities. This regulation opens the way for syari'ah mutual funds to provide funding for real sector projects to small and medium enterprises in accordance with syari'ah principles, the requirement that these securities get investment grade ratings from rating agencies. Although the concept is interesting but until now there is no investment manager who publish it because the financing of the real sector has a more complex risk.

\footnotetext{
${ }^{10}$ Wawan Hendrayana, 'Kondisi Terkini Reksadana Indonesia' (Infovesta, 2015) $<$ https:// www.infovesta.com/index/article/articleread/9bed87e8-d289-4958-903d-789d82073d11> accessed 25 November 2016.
} 
The problems in this research are what is the interpretation of the regulation of sharia economic principles in Indonesia?, and how is the management of Syari'ah Mutual funds based on Syari'ah economic principles in Indonesia?

\section{Syari’ah Capital Market}

The definition of capital market in accordance with Law Number 8 of 1995 concerning Capital Market (UUPM) is an activity concerned with the public offering and securities trading, public company related to the securities it publishes, as well as institutions and professions relating to muamalah securities. Implementation of syari'ah principles in the capital market must be based on Al Quran as the highest source of law and Hadith of Prophet Muhammad SAW. Furthermore, from both sources of law, the scholars do the interpretation of syari'ah capital market which is then called the science of jurisprudence. One of the discussions in the science of fiqh is the discussion of muamalah, namely the relationship among fellow human-related trade. Based on that the activities of syari'ah capital market developed with the basis of figh.

Capital Market Instruments in Indonesia are shares, shares are stocks or stocks are proof of ownership of capital in a limited liability company. In transactions purchased on the stock exchange, stocks are often also called shares is the most dominant instrument traded. Bonds are proof of debt from an issuer that is guaranteed by the insurer containing the promise of interest or other appointments and repayment of the principal on the due date. Mutual fund, according to Law Number 8 of 1995 Concerning Capital Market, mutual fund is a vessel used to raise funds from the investor community to be invested in securities portfolio by the investment manager. Warrant by law is the securities issued by a company, which entitles the securities trader to order shares of the company at a specified price, with a period of six months or more.

The syari'ah capital market instruments in Indonesia are syari'ah Share, ${ }^{11}$ the term stock can be interpreted as a certificate of capital participation from a person

${ }^{11}$ Burhanuddin S, Aspek Hukum Lembaga Keuangan Syari'ah (Graha Ilmu 2010).[35]. 
or a legal entity against a company. Shares are a written proof for investors to the ownership of a company that has gone public. Through the purchase of shares in certain amounts, the stakeholder has the right and obligation to share the results and risks with the entrepreneurs, attend the General Meeting of Shareholders and even take over the ownership of the company. Syari'ah bonds are letters of cooperation that have a more diverse scope than just a letter of recognition of debt. The diversity is influenced by the various contracts that have been used. Such as mudaraba, murabaha, salam, istishnaandijara. Syari'ah mutual funds are mutual funds operating under the terms and principles of islamic syari'ah, either in the form of a contract between the custodian bank as the owner of the property (shalib al-mal/rabb al-mal) with the Investment Manager, as well as the management of the investment fund as the representative of shalib Al-mal, or between the Investment Manager as the representative of shalibal-mal with the holders of the participation unit.

Syari'ah Asset Backed Securities are securities issued by the EBA sharia collective investment contract whose portfolio consists of financial assets in the form of claims arising from commercial paper, invoices arising in the future, the sale and purchase of physical assets held by a financial institution, investments guaranteed by the government, means of increasing investment or cash flows and equivalent financial assets, in accordance with the principles of syari'ah. Pre-emptive Rights (rights issue), the Fatwa DSN-MUI Number: 65/DSN-MUI/III/2008 regarding Pre-emptive Rights (HMETD) ensures that the halal investment in capital markets does not stop only on securities instruments named shares, but also on derivative products. The derivative product (derivative) rated according to the DSN criterion is (HMETD). Products that are inherent and inherent with the parent product it becomes investment products that already meet the criteria of DSN. Syari'ah warrant, the Fatwa DSN-MUI Number: 65/ DSN-MUI/III/2008 regarding Pre-emptive Rights (HMETD) ensures that the halal investment in capital markets does not stop only on securities instruments named shares, but also on derivative products. The derivative product (derivative) rated according to the DSN criterion is (HMETD). Products that are inherent and inherent with the parent product it becomes investment products that already meet the criteria of DSN. 


\section{Interpretation of Sharia Economy Principles in Indonesia}

According to M. A. Mannan syari'ah economy is a social science studying the economic problems of society inspired by syari'ah values. So in his journey according to mannan argue that syari'ah economics is positive and normative economics, because both are interconnected in forming a good economy in its evaluation later. ${ }^{12}$ However, in many ways related to finance, Islam has several principles that distinguish it from other economic systems: ${ }^{13}$

1. Principle of Tawheed, good Tawheed is expected to form integrity that will help the formation of good goverment. The principle of faith becomes the ultimate foundation that sustains for other principles. The awareness of tauhid will lead to the belief of the afterlife simultaneously, so that an economic actor does not pursue material gain alone. Another positive impact of the principle of monotheism in the islamic economic system is the anticipation of all forms of monopoly and concentration of economic power in a person or one group only

2. Principle of Justice, implementation of justice in economic activity is in the form of rules of interaction and transaction principle that prohibits the existence of elements: ${ }^{14}$ a) Riba, is one hurdle that is often tempting many people to gain profit. Islam forbids usury in all its forms, as it contradicts the principles of humanity, brotherhood and compassion, b) Maysir, Maysir language with the meaning qimar, meaning gambling, that is all forms of speculative behavior or the chances. Islam forbids all forms of gambling. This is because gambling with all its forms contains speculative elements and leads to a great deal of harm. c) Gharar, it is simply concluded that the gharar is related to the lack of clarity about something in a transaction. d) Haram, Economic activity, in the syari'ah financial system, as a subdivision of mu'amalah study entered into the ammah worship group. Where, the rules of governance are more general. According to

${ }^{12}$ Mustafa Edwin, Pengenalan Eksklusif Ekonomi Syari'ah (Kencana Perdana Media Group 2006).[17].

${ }^{13}$ Mursal dan Suhadi, 'Implementasi Prinsip Islam Dalam Aktivitas Ekonomi: Alternatif Mewujudkan Keseimbangan Hidup’ (2015) 9 Jurnal Penelitian.[71-72].

${ }^{14} \mathrm{ibid}$. 
the Hanafi cleric, the prohibition within islamic law consists of two categories, namely material prohibitions (matter, substance, or object) and prohibition due to external factors.

3. Principles of Maslahat, economic activity is considered to meet the maslahat if it meets two elements, namely the obedience (kosher) and useful and bring goodness (thayyib) for all aspects are integral. Thus, such activity will certainly not cause harm.

The regulation of syari'ah economic principles in Indonesia is regulated in AlQur'an, Sunnah Rosul, Ijtihad, and the DSN-MUI Fatwa and compilation of islamic law. Basically sharia economic principles are in the field of Banks and Non-Bank financial institutions. Because it is regulating the principles of syari'ah economy is not only regulated by a single law.

1) Legislation in the field of Bank Financial Institution.

a. Law: Law No.10 of 1998 on Amendment to Law No.7 of 1992 on Banking;

b. Law No.21 Year 2008 on Syari'ah Banking;

c. Bank Indonesia Regulation;

d. Financial Services Authority Regulation Number 19/POJK.04/2015 On Issuing and Requirements of Syari'ah Mutual funds.

2) Legislation in the field of Bank Financial Institutions.

a. Insurance: Law No.40 of 2014 on Insurance, PP No.39 of 2008 on the Second Amendment of PP No.73 of 1992 on the Implementation of Insurance Business;

b. Syari'ah Pawnshop (Rahn): Fatwa DSN-MUI Number: 25/DSN-MUI/ III/2002 on Rahn and Fatwa DSN-MUI Number: 26/DSN-MUI/III/2002 on Rahn Gold.

\section{Management of Sharia Mutual Funds Based on The Sharia Economics Principles in Indonesia}

There are two important things to consider in measuring the performance of sharia mutual funds, namely: ${ }^{15}$ the rate of return obtained is equal to or greater than a certain portfolio yield rate with a risk equal to or less than the market risk level.

${ }^{15}$ Nur Aini Kandarisa, 'Perkembangan Dan Hambatan Reksadana Syari'ah Di Indonesia: Suatu Kajian Teori' (2014) 2 Jurnal Akutansi Unesa $<$ http://jurnalmahasiswa.unesa. ac.id/index.php/jurnal-akuntansi/article/view/6790>.[8-9]. 
Diversify so as to minimize the risk that is not systematic measured by calculating the correlation between the level of mutual funds yield syari'ah with the results of capital market portfolio. Syari'ah mutual fund performance does not always guarantee good performance, but syari'ah mutual funds guarantee performance in accordance with the principles of syari'ah and lawful. Syari'ah mutual fund performance depends on how the role of investment manager to operate its performance system and maintain creditability. Good and bad performance of mutual funds can affect the growth of net asset value; if the performance is good then the value of net assets will rise so as to increase the investment value to the holder of participation unit. While the investment performance is bad then the net asset value will decrease, thus decreasing the investment value owned by the investor. In the character of the instrument of mutual fund investment syari'ah is not much different from conventional mutual fund. ${ }^{16}$

Syari'ah mutual funds are based on sharia principles, a simple process of mutual fund investment management syari'ah can be described as follows:

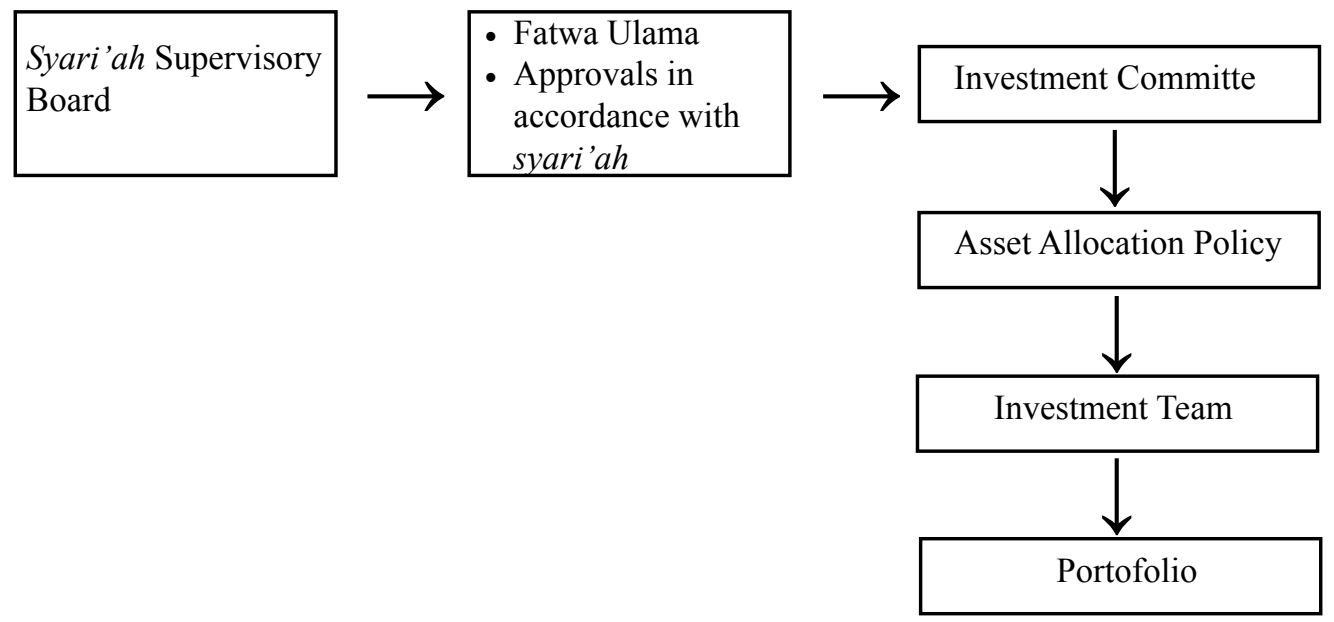

Above picture describes the process of managing syari'ah mutual funds, the supervisor of syari' ah is an institution authorized to examine, explore and formulate the value and principles of sharia law in the form of fatwa to be used as guidance 
in transactions activities that occur in syari'ah financial institutions' Ah and agree on the effects in accordance with the principles of syari'ah. The guidelines are used by the investment committee to formulate the objectives, policies and investment strategies which are then implemented by the investment team in the form of securities portfolio in accordance with the principles of syari' $a{ }^{17}$

In mutual fund contracts involves two parties who each have certain rights and obligations. The relationship between the parties in mutual funds is not a creditor relationship with the debtor, but a partnership relationship between the parties of investors/investors with the investment manager who acts as a fund manager (mudharib). ${ }^{18}$ In general, the operational mechanism in shariah mutual funds can be divided into two, namely between the investor and the investment manager and between the investment manager and the investment user. The operational mechanism between investor and investment manager is done by wakalah system. While the operational mechanism between investment managers and investment users is done with mudarabah system. ${ }^{19}$

In conducting transactions syari'ah mutual funds are not allowed to perform speculation actions, which contain gharar such as najsy (bogus supply), ihtikar and other speculative acts. "Bukhari and Muslim narrated from Ibn Umar who said that Prophet Muhammad SAW forbade an-Najsy (bid something not to buy but raise prices)" Mutual fund transaction products in general such as spot, forward, swap, option and other products Usually done mutual funds should be the subject of research and assessment of shariah mutual funds. To discuss issues that require research and assessment, such as selecting investment companies, income purification, and profit sharing formulas and so on, a Sharia Supervisory Board appointed by the MUI should be established.

${ }^{17}$ ibid. [7].

${ }^{18}$ M. Rasyid Ridha, 'Peranan Reksadana Syari’ah Dalam Peningkatkan Investasi Di Indonesia,Transparency' (2013) 2 Jurnal Hukum Ekonomi <https://jurnal.usu.ac.id/index. php/transparency/article/view/3924>.[4].

${ }^{19}$ Hanif, 'Reksa Dana Syari'ah' (2010) 2 Fakultas Syari'ah IAIN Raden Intan Lampung.[27]. 
The return on investment in mutual property owned by investors in syari'ah Mutual Fund is distributed proportionally to the investors. The investment proceeds should be cleared from non-halal elements, so the investment manager must separate the income share that contains the non-halal elements of the halal (tarfiq al-halal min al-haram). revenue. Therefore, short term placements on unconventional conventional giro will be cleared through the cleansing process. Economics. syariah which are applied in regulations and management mutual funds syariah based on a postulate Arro'yu or with ijtihad with the methods ijtihad problems for public interest.

\section{Conclusion}

Based on the results of research and discussion above, it can be concluded as follows: there are three principles of syari'ah economy namely the principles of Tawheed, principles of justice, and the principles of welfare. The regulation of syari'ah economic principles in Indonesia is regulated in the DSN-MUI Fatwa and compilation of economic islamic law. Basically sharia economic principles are in the field of financial institutions of Banks and Non-Bank financial institutions. Because it is regulating the principles of syari'ah economy is not only regulated by a single law economics. Syari'ah for the management mutual funds syari'ah in ijtihad through Ar- ro' yu or with ijtihad to the question of the problem.

The mechanism of transactions in investing through mutual funds syari'ah should pay attention to things that are not against the islamic syari'ah. The application of the transaction contract must not be contradictory to the islamic syari'ah, whether prohibited because forbidden in addition to the substance, which contains tadlis, ihtikar, ba'i najasy, garar, and usury, as well because unauthorized, unfulfilled conditions, ta'alluq occurs, and there are two contracts in one transaction simultaneously.

\section{Bibliography}

\section{Books}

A. Djazuli dan Yadi Janwari, Lembaga-Lembaga Perekonomian Umat (PT Raja Grafindo Persada 2002). 
Alie Yafie, Fiqh Perdagangan Bebas (Teraju 2003).

Azizy AQ, Membangun Fondasi Ekonomi Umat (Pustaka Pelajar 2005).

Burhanuddin S, Aspek Hukum Lembaga Keuangan Syari'ah (Graha Ilmu 2010).

Heri Sudarsono, Bank and Syariah Mutual Fund (Econosia 2005).

Mustafa Edwin, Pengenalan Eksklusif Ekonomi Syari'ah (Kencana Perdana Media Group 2006).

Nasarudin Irsan dan Indra Surya, Aspek Hukum Pasar Modal Indonesia (Kencana 2007).

Sumantoro dalam Khaerul Umam, Pasar Modal Syari'ah Dan Praktik Pasar Modal Syari'ah (Pustaka Setia 2013).

\section{Journals}

Aini Masruroh, 'Konsep Dasar Investasi Reksadana' (2014) 1 Jurnal Filsafat dan Budaya Hukum.

Hanif, 'Reksa Dana Syari'ah' (2010) 2 Fakultas Syari'ah IAIN Raden Intan Lampung.

M. Rasyid Ridha, 'Peranan Reksadana Syari'ah Dalam Peningkatkan Investasi Di Indonesia,Transparency' (2013) 2 Jurnal Hukum Ekonomi <https://jurnal. usu.ac.id/index.php/transparency/article/view/3924>.

Mursal dan Suhadi, 'Implementasi Prinsip Islam Dalam Aktivitas Ekonomi: Alternatif Mewujudkan Keseimbangan Hidup' (2015) 9 Jurnal Penelitian.

Nur Aini Kandarisa, 'Perkembangan Dan Hambatan Reksadana Syari'ah Di Indonesia: Suatu Kajian Teori' (2014) 2 Jurnal Akutansi Unesa <http:// jurnalmahasiswa.unesa.ac.id/index.php/jurnal-akuntansi/article/view/6790>.

Syarifah Gustiawati Mukri, 'Langkah Strategis Optimalisasi Sistem Ekonomi Syariah' (2014) 1 Jurnal Filsafat dan Budaya Hukum <http://journal.uinjkt. ac.id/index.php/salam/article/view/1521>.

\section{Websites}

MUI, 'Decision of Fatwa of Indonesian Ulema Council Number 1 of 2004 on Interest (Intersat/Fa'idah)' (Majelis Ulama Indonesia, 2017) $<\mathrm{http}: / / \mathrm{www}$. mui.or.id $>$ accessed 14 June 2017. 
Wawan Hendrayana, 'Kondisi Terkini Reksadana Indonesia' (Infovesta, 2015) $<$ https://www.infovesta.com/index/article/articleread/9bed87e8-d289-4958903d-789d82073d11 > accessed 25 November 2016.

HOW TO CITE: Nunung Rodliyah dan Risti Dwi Ramasari, 'Implementation of Syari'ah Economic Principles on the Management of Syari'ah Mutual Fund in Indonesia' (2018) 33 Yuridika. 